\title{
Патофизиология и патохистология \\ на рецидивиращата респираторна папиломатоза
}

\author{
Спиридон Тодоров, Силвия Вълчева \\ Катедра по УНГ-болести при УМБАЛ „Ц. Йоанна - ИСУЛ“ ЕАД София
}

\begin{abstract}
The Recurrent Respiratory Papillomatosis is caused by the Human Papillomavirus (HPV). This is an epithelotropic virus, which enters the mucus membrane and the skin, most often when there is a disturbed epithelial barrier. Macroscopically, the laryngeal papillomas are exophitical tumors with a surface consisting of granules, and a pale pink color. Their microscopic construction consists of a stroma, made from connective tissue and blood vessels, covered with multiple layers of flat epithelium. The authors are making a short survey of the pathophysiological and pathohystological features of RRP.
\end{abstract}

\section{Резюме}

Рецидивиращата респираторна папиломатоза се причинява от Human papillomavirus (HPV). Това е епителотропен вирус, който навлиза в лигавицата и кожата най-често при нарушена епителиална бариера. Макраскопски ларингеалните папиломи представляват екзофитни туморни образувания със зърниста повърхност и бледорозов цвят. Микроскопският им строеж е от съединително-тъканна строма и кръвоносни съдове, покрита с многослоен плосък епител. Авторите правят кратък обзор на патофизиологичните и патохистологичните особености на РРП.
$\mathrm{P}$ ецидивиращата респираторна папиломатоза е заболяване с вирусна етиология, причинено от Human papillomavirus (HPV).

HPV е епителотропен вирус, който инфектира базалните клетки на лигавицата и кожата. Инфектирането става най-често при нарушена епителиална бариера, каквато може да се получи при полово сношение или малки дефекти на кожата и лигавиците. Макар че всички клетки в една папиломна лезия да съдържат вирусния геном, експресията на вирусни гени е тясно свързана с клетьчната диференциация. Продукция на вирусни частици може да настьпи само във високодиференцираните кератиноцити. След инфектирането вирусната ДНК може или да се прояви активно, или да остане в латентно състояние, при което лигавицата остава клинично и хистологично нормална. Активирането на вируса може да стане по всяко време по неизвестни засега причини и рецидивите да се проявят след години ремисия.

Репликацията на вируса вътре в епителните клетки уврежда тяхната нормална структура и функция и настъпва пролиферация на ненормални клетки. За репликацията си HPV трябва да активира клетъчната репликационна система на човека. Вирусният геном съдържа три области: една възходяща регулаторна област и две области, свързани с фазата на инфекция - ранна (E) и късна (L). Гените на Е-областта са свързани с репликацията на вирусния геном, с активността на трансформация и са потенциално онкогенни в зависимост от типа HPV. Гените на L-областта кодират структурните вирусни протеини. Гените от ранната фаза - E6, Е7 и отчасти Е5 са отговорни за активиране на папиломния растеж. 
Основното свойство на HPV е да причинява клетъчна пролиферация, макар че интимният механизъм на това въздействие да остава неясен. Сочи ce, че редица продукти на гените от Е-област свързват и инактивират някои тумор-супресорни протеини, напр. p53 и Rb (Swan et al., цит. по Derkay \& Faust $\left.{ }^{1}\right)$. От друга страна HPV активира епидермал-растежния фактор (EGF). Всичко това води до нерегулируема пролиферация на епителните клетки и малигнена трансформация (Vambutas et al., цит. по Derkay\&Faust ${ }^{1}$ ). Тъй като вирусната мултипликация е ограничена в ядрото, то инфектираните клетки показват висока степен на клетьчна атипия. Наличието на койлоцити при хистологичното изследване на папиломите е индиректен показател за наличие на HPV инфекция.

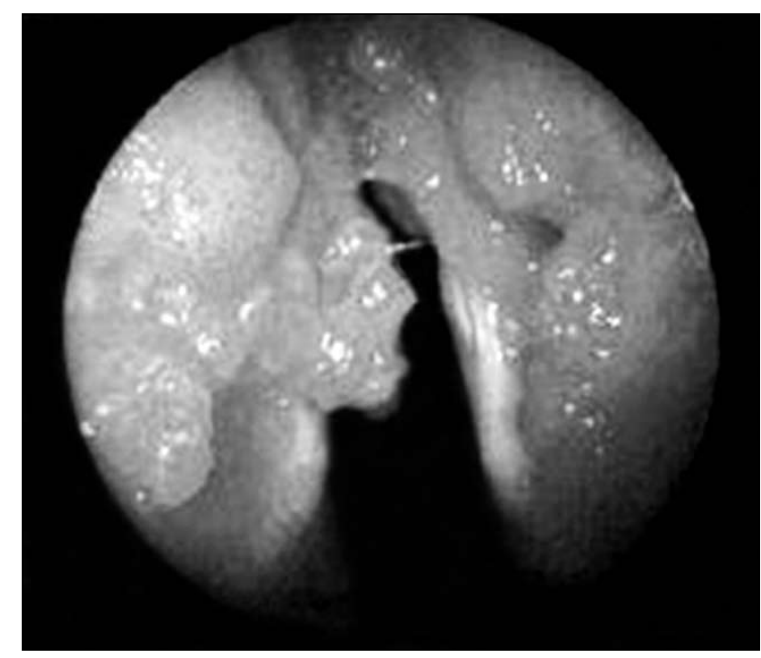

Фиг. 1. Ларингеални папиломи, локализирани върху двете вентрикулни гънки,

лявата истинска гласна гънка и предната комисура

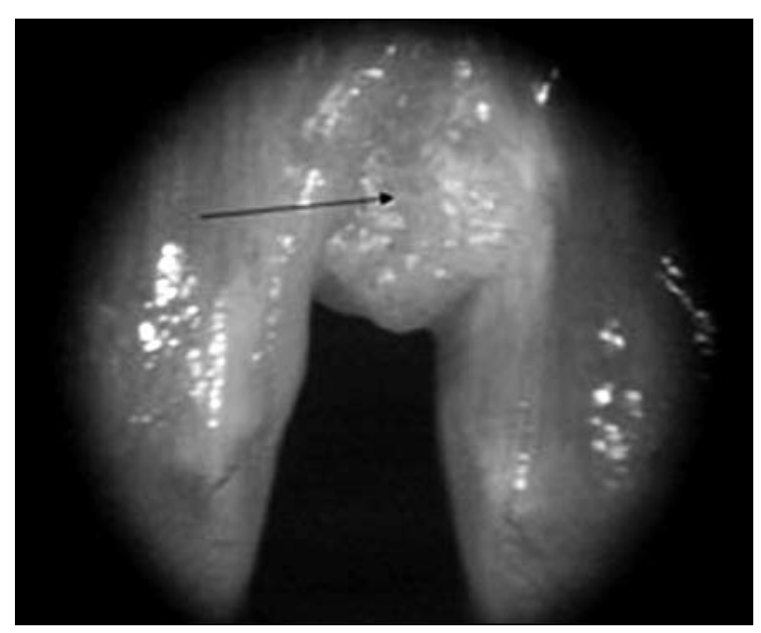

Фиг. 3. Папилом в предна комисура

\section{Патохистология на РРП}

Макроскопски ларингеалните папиломи представляват екзофитни туморни образувания със зърнеста или лобулирана повърхност, наподобяваща цветно зеле или малина. Те се разполагат върху лигавицата на ларинкса на широка основа или на краче. На цвят най-често са бледорозови, но цветьт им може да варира от сивкав (при съпьтствуваща кератоза) до тъмно червен (при по-обилно крьвоснабдяване). Папиломите растат най-често на местата, където се срещат цилиндричния и плоския епител - ларингеалната повърхност на епиглотиса, горния и долния ръб на ларингеалния вентрикул и долната повърхност на истинските гласни гънки (фиг. 1, 2 и 3). При често повтарящи

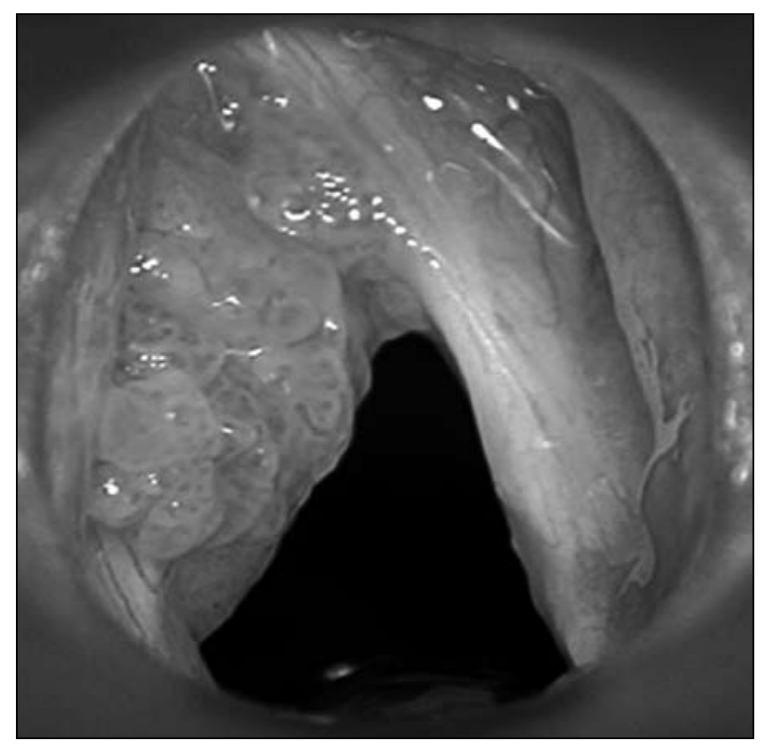

Фuг. 2. Папилом на лявата истинска гласна гънка

се травми, включително и хирургични, въсеносният цилиндричен епител метаплазира в плоськ, което създава условия за ятрогенен допир на двата вида епител и улеснява растежа на папиломите. Така се обяснява бързото нарастване на папиломите при деца с неконтролиран гактроезофагиален рефлукс.

Микроскопски папиломите се състоят от съединителнотъканна строма с кръвоносни съдове, покрита от многослоен плосък епител. Съотношението между стромата и покривния епител може да е различно, поради което някои автори различават твърди и меки папиломи (фиг. 4). 


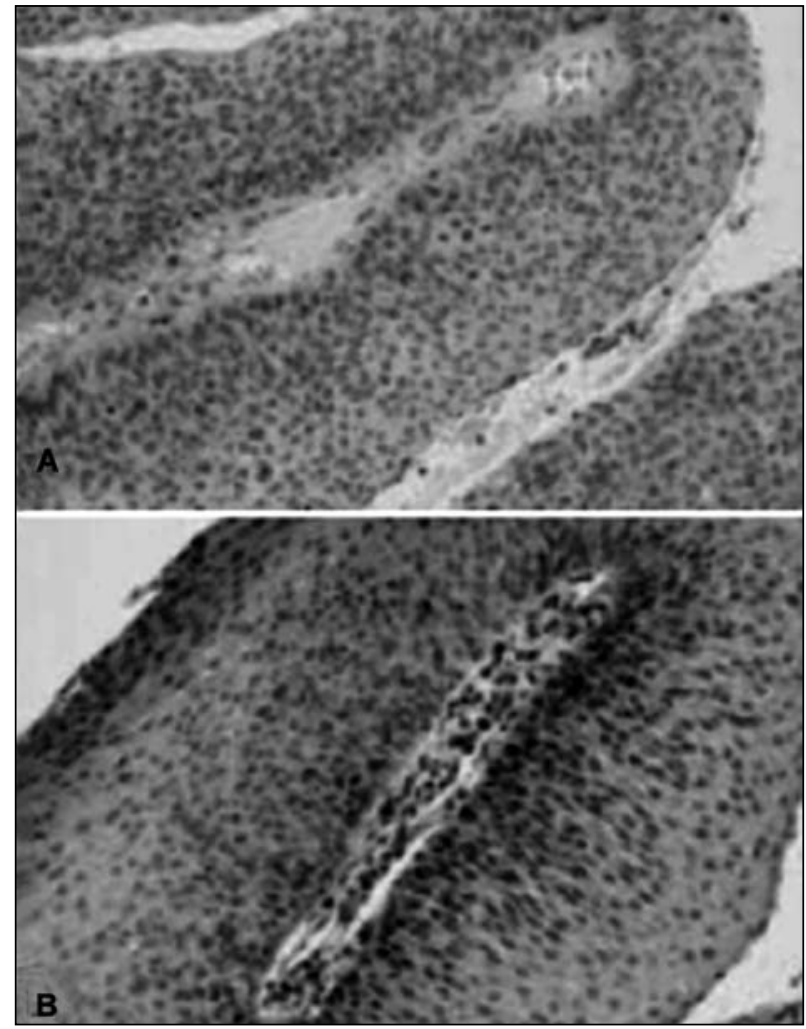

Фиг. 4. Ларингеален папилом. А. Хиперплазия на атипични клетки в покривния епител.

B. Хиперплазия на базалния и парабазалния слой клетки, достигащи до половината om дебелината на епитела.

При твърдите преобладава епительт, а стромата е оскъдна. Този вид папиломи се развива по-често у възрастни болни и при него могат да се наблюдават дегенеративни процеси. При меките папиломи преобладава рехавата и богато кръвоснабдена

\section{Литература}

1. Derkay CS, Faust RA. Recurrent respiratory papillomatosis. In: Cummings Otolaryngology \& Neck Surgery. 4 Ed. - Philadelphia: Elsvier Mosby, 2005; vol. 4: $4370-86$.

2. Kashima H, Mounts P, Leventhal B, Hruban RH. Sites of predilection in recurrent respiratory papillomatosis. Ann. Otol. Rhinolaryngolog. 1993; 102: $580-583$. строма, а епителът се състои от тънък слой кубични или цилиндрични клетки. Меките папиломи са характерни за ювенилната форма на РРП. При нея рядко се наблюдават дисплазия, абнормени митози или хиперкератоза ${ }^{3}$.

Базалният слой може да бъде нормален или хиперпластичен, а в епителния слой се откриват койлоцити като израз на HPV инфекция.

Койлоцитът (от грьцки - koilos - т.е. празен) е уголемен кератиноцит, който се намира в горните слоеве на stratum spinosum и се разпознава по светлото хало около клетъчното ядро. Последното изглежда сбръчкано и пикнотично в тъканните препарати и уголемено - при цитонамазка. Ядрото може да е билобарно, а понякога клетката може да съдържа две ядра (фиг. 5).

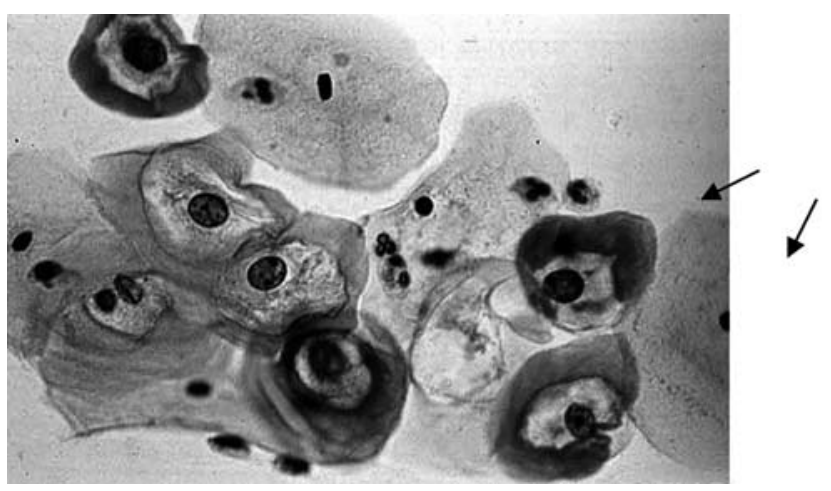

Фие. 5. Койлоцити

Патохистологичните различия между твърдите и меките папиломи играят важна роля в начините на предаване на инфекцията и клиничния ход на заболяването.

3. Abramson AL, Steinberg BM, Winkler B. Laryngeal papillomatosis: clinical, histopathological and molecular studies. Laryngoscope 1987; 97: $678-685$. 